\title{
Edu-Kit "Our Coffee" Development on Problem Based Learning Model for Vocational Agribusiness and Agrotechnology Programs on Material Separation Mixture
}

\author{
https://doi.org/10.3991/ijim.v14i12.15571 \\ Sofiana Nur Fadilah, Siti Marfu’ah, Surjani Wonorahardjo $\left({ }^{\bowtie}\right)$ \\ State University of Malang, Malang, Indonesia \\ surjani.wonorahardjo@um.ac.id
}

\begin{abstract}
Student achievement in chemistry is relatively low because chemistry topics are not integrated with students' expertise programs. The lack of variation in teaching material and learning model also reduces the motivation to study chemistry. One of the science-chemistry materials in vocational high schools is separation of mixture, taught in the agribusiness and agro technology specialization programs. Many business sectors such as cafes are starting to stand in the community, requiring coffee serving skills and also knowledge about coffee that can be viewed from the chemistry side. Chemical changes due to coffee cultivation and the processes through which coffee can be consumed can be learned through interactive and communicative teaching materials.

One way to present and integrate coffee topics in learning is to develop an Edu-Kit which contains problems in coffee that are integrated with separation of mixture topic. Separation of mixture is contained in the 2013 Curriculum. The choice of problem-based learning models is assessed according to the characteristics of vocational learning, which is to present real problems and solve them while learning the concepts needed. The Edu-Kit development uses the research and development (R\&D) method of Borg and Gall. E-book was chosen as an application in the development of Edu-Kit which includes text, sound, picture and video. Validation data were collected from 2 validators and readability tests by students. Data were analyzed using quantitative and qualitative techniques. The effectiveness of the Edu-Kit uses quasi experimental, pretest and posttest designs. There were 62 samples determined by the saturation sampling technique. The sample is divided into two classes, namely the experimental and control classes. Edu-kit effectiveness from posttest scores, analyzed using the Mann Whitney U Test using SPSS. The results of Edu-kit development obtained an average percentage of validation of $91.90 \%$ with very decent criteria. While the results of the effectiveness test showed that the use of Edu-kit made students' understanding better in mixed separation material.
\end{abstract}

Keywords - Edu-Kit, Coffee, Problem Based Learning, Separation of mixture topic, Vocational High School 


\section{Introduction}

Vocational High School (VHS) is an educational institution that aims to prepare students to work in a field, equipping with science, technology and art to be able to develop themselves independently or at a higher level [1][21]. Specific subjects at VHS, including normative, adaptive, and productive [1]. One productive subject is the production of plantation and herbal commodity processing, which requires basic knowledge of chemistry. Studying chemistry in vocational schools is related to nature so that it is not only the mastery of knowledge about facts, concepts or principles. But it also becomes a means of applying knowledge in daily life [21]. One of the chemistry materials in VHS that is related to daily life is mixed separation. Although related to daily life, students still have difficulty in understanding mixed separation. First, due to students' understanding in learning the basic principles of the separation method and how the separation process occurs is still low [2]. For example, in the distillation separation technique, students only know the basics of distillation and distillation tool drawings without understanding how the processes and instruments are used in the distillation technique. Second, learning in schools is still teacher-centered, while students are less actively involved in the concept discovery process [3]. Third, in the learning process teachers only prioritize the final product as the only aspect of assessment without regard to other aspects such as aspects of attitudes and processes that are in accordance with the nature of science [4].

The material of mixed separation is related to the subject matter of the production of seasonal plantations such as cocoa, coffee, pepper, and candlenut which are learned in vocational agribusiness and agrotechnology programs, from land preparation to post-harvest handling. However, the delivery of mixed separation material is less integrated with plantation crop production subjects [5]. This causes students to be less interested in chemical materials because they think chemistry is not related to agribusiness expertise programs. The topic of cocoa or coffee in the subject of seasonal estate crop production is a topic that's familiar to students. However, they assume that the content of coffee is only caffeine, even though coffee have other ingredients that cause different tastes. Differences in regional origin, type of coffee, caffeine content, and how to brew coffee can produce different flavors and aromas of coffee [6]. This proves that chemistry is related to agribusiness expertise programs, especially in mixed separation materials.

Submitting the previous material such as differences in elements, compounds and mixtures can make it easier for students to learn the separation of the mixture [7]. Providing apperception related to seasonal crop production material, such as the work of a barista can increase student motivation. And the existence of experimental activities that can provide direct learning experience in learning to separate the mixture. Learning experiences like this are still lacking in the teaching materials used at school. The majority of teaching materials available are still limited to the material description and drawing of the separation tools without further explanation related to the process of the separation [22]. In addition, teaching materials do not link between chemical materials and seasonal plant production materials. This causes students to feel that chemistry is not important, because it is not related to productive agribusi- 
ness subjects [8]. Therefore, it is necessary to develop chemical teaching materials that support and cover a subject in an agribusiness and agrotechnology expertise program. One form of supporting teaching materials is Coffee Edu-Kit.

Edu-Kit (Education Kit) is one of the educational tools to facilitate certain topics in the student environment that can be included in the school curriculum. The 2013 curriculum policy has elaborated students' abilities on the dimensions of life skills, collaboration, critical thinking and creative thinking [9]. But the reality explains that many curriculum implementations are out of context and are not oriented towards achieving abilities in understanding chemistry. But it is more focused on achieving competency targets that are described in academic values alone [10]. In addition, the 2013 curriculum is also related to the demands of the Industrial Revolution 4.0. The Industrial Revolution 4.0 is a strategic and drastic change about the production patterns that collaborate people, technology/machines and big data [11].

Therefore, if learning is based on the 2013 curriculum and the Industrial Revolution 4.0, teachers must make the learning process more interesting and enjoyable and can improve life skills, collaboration, critical thinking and creativity [23]. One way that can be used is the use of technology-based teaching materials that aim to increase learning motivation, reduce boredom, and can increase understanding [24]. One form of technology-based teaching material is e-book [12]. E-book is an application that can be used to develop teaching materials with a digital display that is equipped with text, image, and sound.

Besides the importance of using teaching materials, the use of learning methods also needs to be considered. Learning methods that must be used are student-centered and constructivist. One of the models is Problem Based Learning, consisting of five stages, namely problem orientation, organizing student learning, independent or group investigations, developing and presenting results, and evaluating problem solving processes [13]. The Problem Based Learning model is suitable for use in learning in Agribusiness Vocational Schools, because the focus of Problem Based Learning (PBL) is to present real problems or simulations to students. Then students are asked to find a solution through a series of research and investigation activities (identifying problems, collecting data, using data) based on theories, concepts, principles learned from various fields of science [14]. PBL links hard skills, critical thinking skills, collaborates, seeks information, obtains and evaluates data, organizes and maintains data, interprets and communicates findings [25]. Thus, students' cognitive abilities in reasoning and critical thinking can develop. Likewise, the affective development of students has increased with the ability to work in teams, empathy and respect for the viewpoint of others [15].

Based on these problems, it is very important to develop coffee Edu-kit teaching materials on mixed separation material with technology-based problem-based learning models. This research and development is expected to increase students' understanding of mixed separation material and integrated with expertise program material. 


\section{$2 \quad$ Methodology}

\subsection{Development of Edu-Kit}

The outline of the research and development (R\&D) model in this study is explained according to Figure 1.

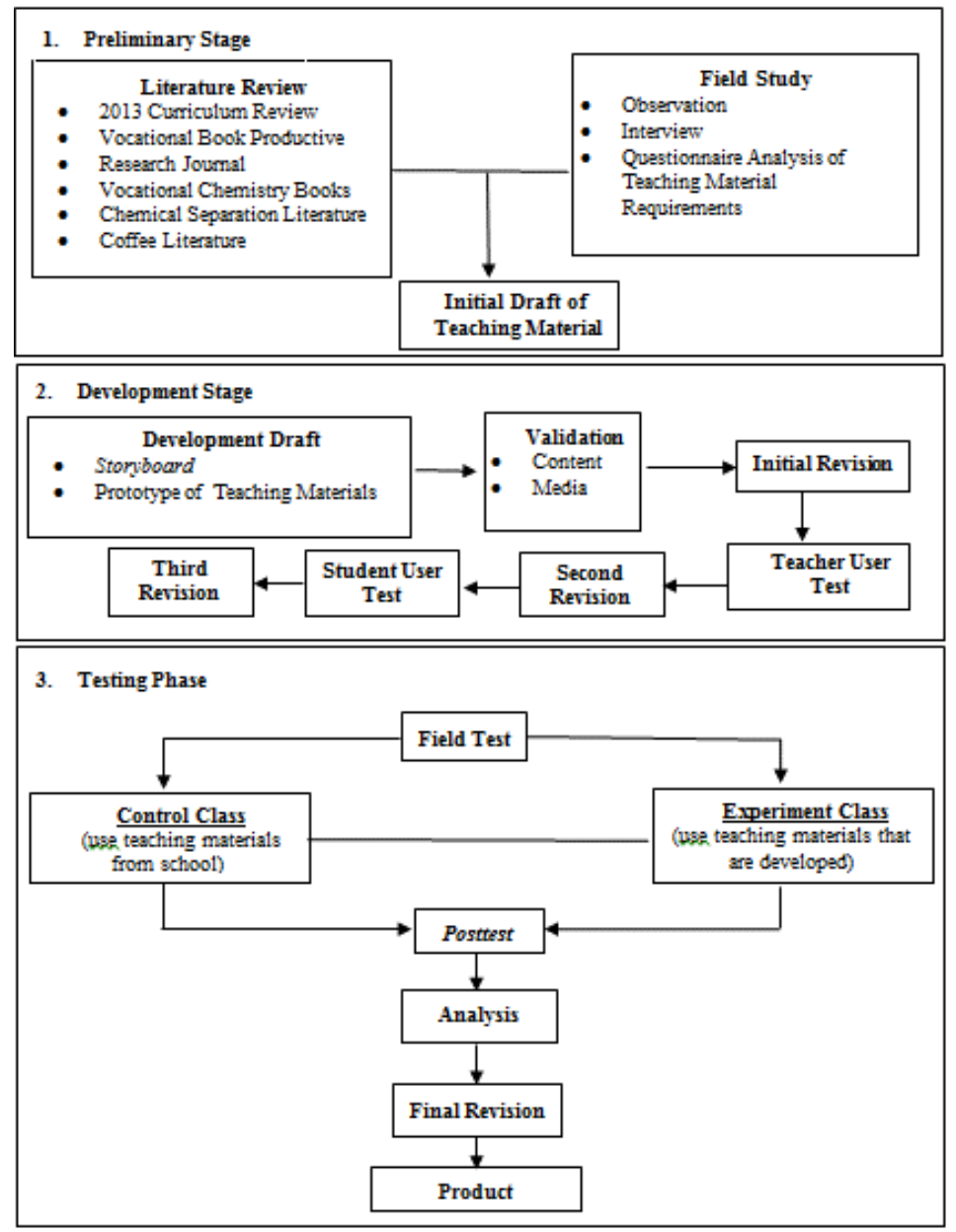

Fig. 1. Scheme of Research and Development (R\&D) Method

The development of teaching materials will use a research and development (R\&D) model from Borg and Gall (1989), which consists of 10 stages. By Sukma-dinata (2006) grouped into 3 stages, namely: 1) initial stage, (2) development stage, (3) testing phase. 
Before teaching materials are used for readability tests for students and trials in class, content validation is done first. The validators of teaching materials are experienced chemistry lecturer and teachers. The instrument used was a validation questionnaire with an assessment component in the form and appearance of teaching materials. Quantitative validation questionnaire analysis uses a Likert scale with values 4, 3, 2 , and 1 . Assessment by the validator is transformed on a scale of values adjusted to the eligibility criteria for teaching materials in Table 1 . While qualitatively obtained from the results of suggestions and comments from the validator.

Table 1. Eligibility Criteria for Teaching Material

\begin{tabular}{|c|l|c|l|}
\hline Scale & \multicolumn{1}{|c|}{ Criteria } & Percentage & \multicolumn{1}{c|}{ Description } \\
\hline 1 & Very less & $0-55$ & Revision \\
\hline 2 & Less & $56-70$ & Needs revision \\
\hline 3 & Worth & $71-85$ & Partial revision \\
\hline 4 & Very worth & $86-100$ & No revision needed \\
\hline
\end{tabular}

The percentage of eligibility for teaching materials can be calculated using the formula.

$$
P=\frac{\sum x}{\sum x i}
$$

Description:

$\mathrm{P}=$ percentage of score validator's answer

$\sum x=$ total score of the validator's answer

$\sum x i=$ highest score

For validation of competency test questions, the assessment is reviewed from 3 domains namely: material domain, constructive, and language domain assessment. The competency test questions are tested first to determine the level of difficulty, the difference test, validity, and reliability. The trial was conducted on students of class XI Vocational High School program.

\subsection{Effectiveness of Edu-Kit}

This study uses a quasi-experimental design, posttest only involves two classes, the experimental class and the control class. The experimental class uses teaching materials that are developed, while the control class uses teaching materials at school. The purpose of this design is to determine student achievement in the experimental class, test results are analyzed to determine differences in the average value of students in the experimental class and the control class. The experimental research design is shown in Table 2.

Table 2. Research Design

\begin{tabular}{|l|c|c|c|}
\hline \multicolumn{1}{|c|}{ Class } & Pre test & Treatment & Post test \\
\hline Experiment & $\mathrm{O}$ & $\mathrm{X}$ & $\mathrm{O}$ \\
\hline Control & $\mathrm{O}$ & - & $\mathrm{O}$ \\
\hline
\end{tabular}


Description:

$\mathrm{O}=$ observation (measurement) after treatment

$\mathrm{X}=$ independent variable (teaching material as a result of development)

To determine the effectiveness of teaching materials developed by comparing posttest average scores and the percentage of achievement of minimum graduation criteria between the experimental and control classes. The minimum graduation criterion is the lowest criterion for stating student achievement. To find out significantly that the two classes showed differences in learning outcomes, a t-test was used using SPSS for windows programming. Calculation of the average post-test score and the percentage of achievement of the minimum passing criteria using the following formula.

$$
\begin{gathered}
\text { Average posttest score }=\frac{\text { number of grade by student }}{\text { number of students }} \\
\% \text { Mastery learning }=\frac{\text { number of student reaching KKM }}{\text { total number of students }} \times 100 \%
\end{gathered}
$$

\section{$3 \quad$ Result and Discussion}

Basic competence of mixed separation material includes prerequisite material (material classification), definition and purpose of separation, qualitative and quantitative analysis, separation methods covering basic principles, tools and processes of separation, and application of separation in agriculture and other fields. This mixed separation material is associated with productive subjects namely the production and processing of plantation and herbal commodities. The results of developing Edu-kit in mixed separation material with problem-based learning model for vocational agribusiness and agrotechnology programs can be described as follows:

Student orientation to problems. The first activity carried out in this stage is to explain the learning objectives to be achieved by the teacher, then convey related logistical needs, propose a problem that must be solved by students, motivate students to be directly involved to carry out problem solving activities of their choice. The result of the problem orientation phase is presented in Figure 2.

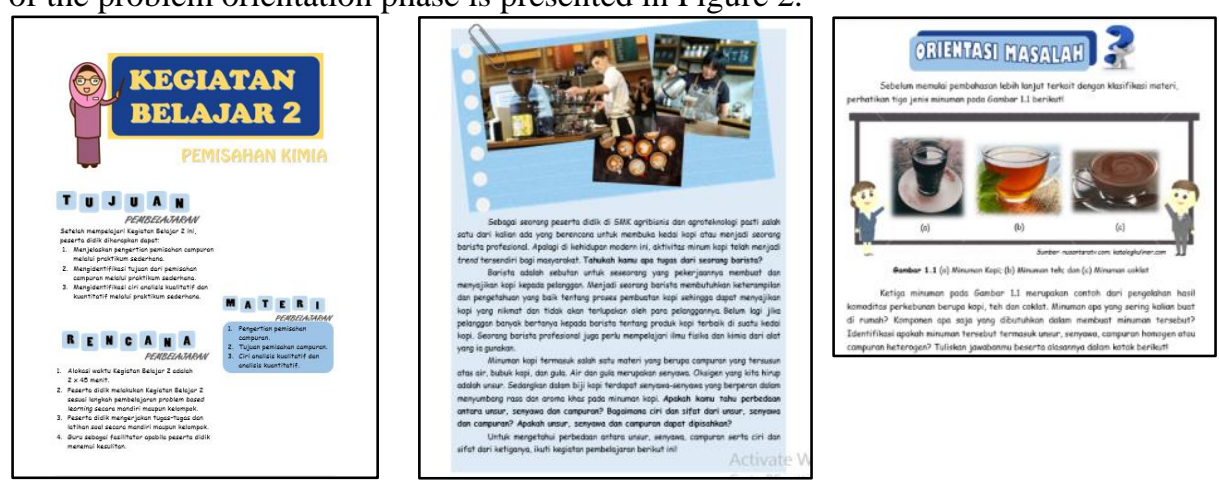

Fig. 2. The result of the problem orientation phase 
Organizing students to learn. The teacher can perform his role to help students in defining and organizing learning tasks related to the problem presented. The result of the organizational problem phase is presented in Figure 3.

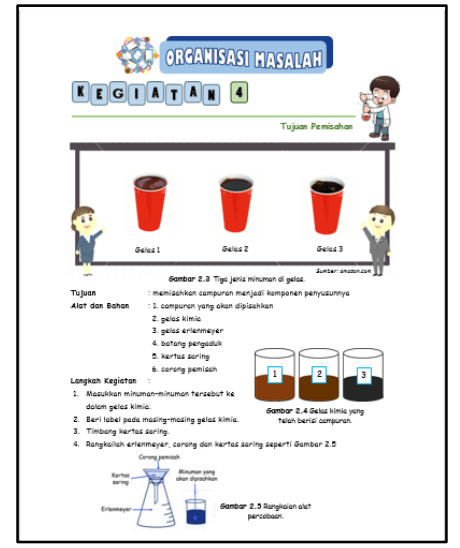

Fig. 3. The result of the organizational problem phase

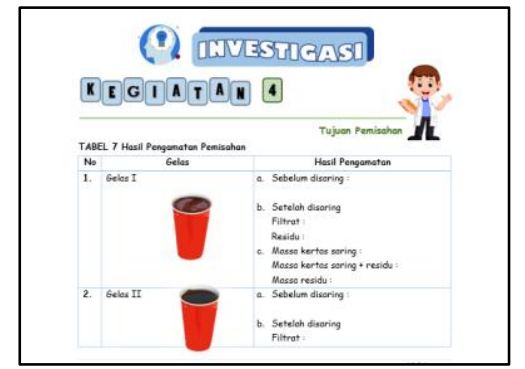

Fig. 4. The result of the investigation phase

Guide individual and group investigations. The teacher makes an effort to encourage students to gather relevant information, encourage students to conduct experiments, and to get enlightenment in problem solving. The result of the investigation phase is presented in Figure 4.

Develop and present the work. The teacher helps the students in planning and preparing appropriate work for example reports, videos or models, and the teacher helps students to share assignments between members in the group. The result of present the work phase is presented in Figure 5.

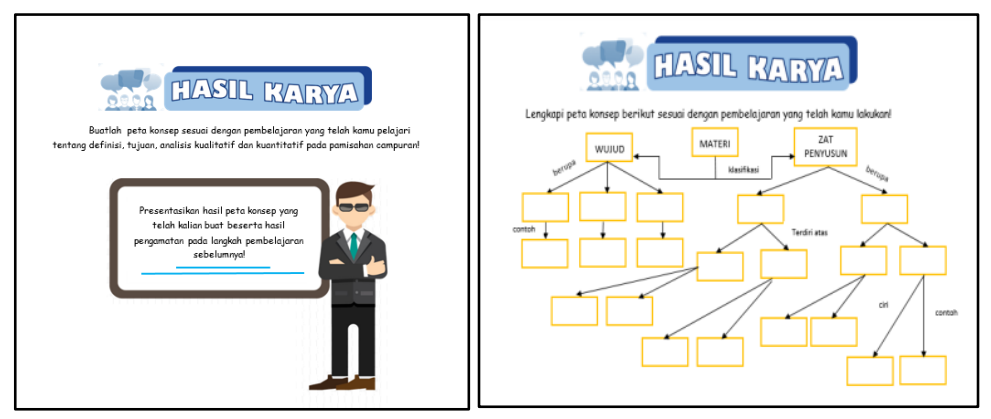

Fig. 5. The result of present the work phase

Analyze and evaluate the problem-solving process. The teacher helps students reflect or evaluate their investigation in every process they use. The result of the evaluation phase is presented in Figure 6. 


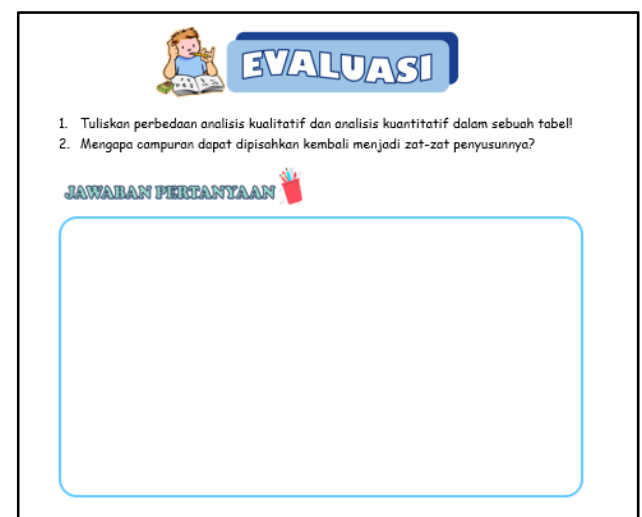

Fig. 6. The result of the evaluation phase

\subsection{Validity of edu-kit development}

Data obtained from the validator in the form of quantitative and qualitative, while from students in the form of quantitative data obtained from the readability test questionnaire.

Validation by validator: Quantitative data were obtained by calculating the percentage score of each aspect assessed by the validator then described in accordance with the eligibility criteria of teaching materials. Aspects in the questionnaire evaluation of teaching materials include the appropriateness of appearance and presentation and appropriateness of the contents in Edu-kit. Aspects of the learning plan assessment questionnaire include aspects of identity and competence, development of learning materials and resources, scenarios of learning activities, and assessment.

Assessment of the appropriateness of appearance and presentation is related to the format and layout of teaching materials. An interesting display of teaching materials can affect students' learning motivation to learn material on teaching materials. There are 9-10 aspects of evaluating the appropriateness of the appearance and presentation of each learning activity. Quantitative data analysis of the feasibility aspects of the appearance and presentation of the Edu-kit is presented in Table 3.

Table 3. Display and Presentation Eligibility Data on Edu-Kit

\begin{tabular}{|c|l|c|c|}
\hline No & \multicolumn{1}{|c|}{ Appearance and Presentation } & Validator 1 (\%) & Validator 2 (\%) \\
\hline 1 & Early part of the Edu-kit & 87,5 & 85 \\
\hline 2 & Learning activities 1 & 91,67 & 100 \\
\hline 3 & Learning activities 2 & 91,67 & 100 \\
\hline 4 & Learning activities 3 & 97,22 & 100 \\
\hline 5 & Learning activities 4 & 94,44 & 100 \\
\hline \multicolumn{2}{|c|}{ Average percentage } & 94,75 & Very good \\
\hline
\end{tabular}


The validator's evaluation of the appearance and presentation aspects of the Edu-kit obtained an average percentage of $94.75 \%$. Therefore, in terms of appearance and presentation the Edu-kit that was developed was very well used in learning.

The assessment of the appropriateness of content in the Edu-kit relates to the accuracy of the delivery of material at each stage of problem-based learning. There are 819 aspects of the assessment of the appropriateness of contents in each learning activity. Quantitative data analysis of the content feasibility aspects of the Edu-kit is presented in Table 4.

Table 4. Data on the Content Eligibility Aspect in the Edu-Kit

\begin{tabular}{|c|l|c|c|}
\hline No & \multicolumn{1}{|c|}{ Content Feasibility } & Validator 1 (\%) & Validator 2 (\%) \\
\hline 1 & Early part of the Edu-kit & 93,75 & 100 \\
\hline 2 & Learning activities 1 & 97,86 & 100 \\
\hline 3 & Learning activities 2 & 85,53 & 100 \\
\hline 4 & Learning activities 3 & 93,42 & 100 \\
\hline 5 & Learning activities 4 & 93,42 & 97,36 \\
\hline \multicolumn{2}{|c|}{ Average percentage } & 96,13 & Very good \\
\hline
\end{tabular}

The validator's evaluation of the Edu-kit content assessment aspect obtained an average percentage of $96.13 \%$. Therefore, in terms of the assessment of the contents of the Edu-kit that is developed is very feasible to use in learning.

The assessment of learning plans contained in the Edu-kit developed with the problem based learning model, has 4 aspects of assessment. Aspects of identity and competence have 4 assessment criteria. The aspect of developing material and learning resources has 7 assessment criteria. Scenarios aspects of learning activities have 11 assessment criteria. The evaluation aspect has 3 evaluation criteria. Quantitative data analysis on the learning plan is presented in Table 5.

Table 5. Quantitative Data Learning Plans on the Edu-Kit

\begin{tabular}{|l|l|c|c|}
\hline No & \multicolumn{1}{|c|}{ Aspect } & Validator 1 (\%) & Validator 2 (\%) \\
\hline 1 & Identity and competence & 93,75 & 93,75 \\
\hline 2 & Development of learning materials and resources & 89,28 & 89,28 \\
\hline 3 & Learning activity scenario & 81,81 & 84,09 \\
\hline 4 & Assessment & 83,33 & 91,66 \\
\hline \multicolumn{2}{|l|}{ Average percentage } & 88,37 & Very good \\
\hline
\end{tabular}

The validator's evaluation of the learning plan's assessment obtained an average percentage of $88.37 \%$. Therefore, the learning plan developed from the Edu-kit is very feasible to use in learning.

\subsection{Effectiveness of edu-kit development}

Edu-kit effectiveness test results are done by calculating the average value obtained and calculating the percentage of the number of students who meet the minimum 
completeness criteria values in the two classes tested and also the assessment sheet on aspects of attitude, cognitive and psychomotor during the learning process.

The test results of the students' pretest value analysis. The experimental class and the control class must have the same ability when used as an Edu-kit effectiveness test class. Data from the analysis of the pretest scores of the two classes are presented in Table 6.

Table 6. Data Analysis of Student Pretest Value

\begin{tabular}{|c|c|c|c|c|c|}
\hline No. & Class & Average & Normality & Homogeneity & $\begin{array}{c}\text { The similarity of two } \\
\text { averages }\end{array}$ \\
\hline 1 & Experiment & 60,81 & 0,114 & \multirow{2}{*}{0,251} & \multirow{2}{*}{0,951} \\
\hline 2 & Control & 60,97 & 0,200 & & \\
\hline \multicolumn{3}{|c|}{ Conclusion } & Normal & Homogeneous & No difference \\
\hline
\end{tabular}

Based on Table 6, obtained a significance value of normality of 0.114 and 0.200 which is greater than 0.05 , it can be concluded that the pretest value is normal. For the homogeneity significance value of $0.251>0.05$, it can be concluded that the pretest value is homogeneous. For the significance value of the two similarity tests of an average of $0.951>0.05$, it can be concluded that there is no difference in initial ability between the two classes.

Test results of students' posttest value analysis. Posttest mixture separation material was held at the end of the learning process at the fifth meeting. Posttest is a written test with 20 multiple choice questions. Posttest scores indicate the learning outcomes of students in the experimental class and the control class. Data on students' pretest results from both classes are presented in Table 7.

Table 7. Data Analysis of Student Pretest Value

\begin{tabular}{|c|c|c|c|c|c|}
\hline No. & Class & Average & Normality & Homogeneity & Hypothesis testing \\
\hline 1 & Experiment & 78,22 & 0,000 & \multirow{2}{*}{0,958} & \multirow{2}{*}{0,048} \\
\hline 2 & Control & 74,19 & 0,002 & & \\
\hline \multicolumn{3}{|c|}{ Conclusion } & Not normal & Homogeneous & $\begin{array}{l}\text { There is a } \\
\text { difference }\end{array}$ \\
\hline
\end{tabular}

Based on Table 7, the significance value of normality is 0,000 and 0.002 which is less than 0.05 so it can be concluded that the posttest value is not normal. For the significance value of homogeneity is $0.958>0.05$, it can be concluded that the posttest value is homogeneous. For the results of hypothesis testing used non-parametric Mann Whitney U Test, the significance value is $0.048<0.05$, it can be concluded that there are differences in learning outcomes between the two classes. The experimental class has a higher average pretest value than the control class, so the Edu-kit development results can be categorized effectively for use in learning activities.

The implementation of the learning process in the experimental class and the control class were observed during the learning process. The implementation of the learning process in both classes was observed using an observation sheet from the assessment of attitude, knowledge and skills. This assessment is carried out by the research- 
er by giving a grade according to the assessment rubric that has been made. Data on the average value of the feasibility of the learning process in the experimental class and the control class are presented in Table 8.

Table 8. Data Average Learning Outcomes Value

\begin{tabular}{|c|l|c|c|}
\hline No. & \multicolumn{1}{|c|}{ Aspect } & Experiment Class & Control Class \\
\hline 1 & Attitude & 83,05 & 79,99 \\
\hline 2 & Knowledge & 85,12 & 84,89 \\
\hline 3 & Skills & 78,11 & 74,87 \\
\hline \multicolumn{2}{|c|}{ Average } & 82,09 & 79,92 \\
\hline
\end{tabular}

Observation results from the assessment of attitudes, knowledge and skills show that the experimental class has a higher value than the control class. This is due to the teaching material used in the experimental class related to productive material that is arranged systematically following the stages of problem-based learning that makes it easy for students to understand the learning material.

\section{Conclusion}

Based on the description above, it is concluded:

- The development of a mixed separation Edu kit with a problem-based learning model for Vocational High Schools is appropriate for use in learning.

- The development of a mixed separation Edu kit with a problem-based learning model for Vocational High Schools is effectively used in learning.

- The development of Edu-kits integrated with productive subjects in Vocational High Schools can lead to more meaningful learning and improve learning outcomes in aspects of attitudes, knowledge and skills.

\section{$5 \quad$ References}

[1] Peraturan Menteri Pendidikan dan Kebudayaan Republik Indonesia Nomor 70 Tahun 2013 tentang Kerangka Dasar dan Struktur Kurikulum Sekolah Menengah Kejuruan/Madrasah Aliyah Kejuruan. (Online), diakses 22 Mei 2019. https://doi.org/10.24832/jpnk.v17i2.22

[2] Lestari, Milda Dwi Dwi., Kuswanti, Nur. \& Maulida, An Nuril. 2017. Keefektifan Lembar Kegiatan Siswa Materi Pemisahan Campuran untuk Melatihkan Keterampilan Proses Sains Siswa pada Kelas VII SMP. E-Jurnal Pensa, 5 (1): 1-7. https://doi.org/10.26740/jpps.v6n1. p1196-1203

[3] Fatimah, S. 2010. Pembelajaran Guide Discovery melalui Media LKS Konstruktif untuk Meningkatkan Penguasaan Konsep dan Keterampilan Proses Sains pada Materi Pokok Laju Reaksi. Universitas Lampung: Bandar Lampung. https://doi.org/10.33578/jpk-unri.v3 i2.7782

[4] Nurulita, A.S.2012. Efektivitas Model Pembelajaran Problem Solving dalam Meningkatkan Keterampilan Merumuskan Hipotesis dan Menarik Kesimpulan pada Materi Koloid. FKIP Unila: Bandar Lampung. https://doi.org/10.23960/jppk.v8.i2.201904 
[5] Clarke, R. J. and Macrae, R. 1987. Coffee Technology (Volume 2). Elsevier Applied Science, London and New York.

[6] Clarke, R. J. and Macrae, R. 1987. Coffee Chemistry (Volume 1). Elsevier Applied Science, London and New York.

[7] Farah, A., Monteiro., Calado, V., Franca. \& Trugo. 2006. Analytical, Nutritional and Clinical Method Correlation Between Cup Quality and Chemical Attributes of Brazilian Coffee. Food Chemistry (Science Direct) 98: 373-380. https://doi.org/10.1016/i.foodchem. 2005.07.032

[8] Retnoningrum, Ambar. 2016. Penggunaan Pendekatan Saintifik dalam Bahan Ajar berbantuan MultimediaMateri Konsep Larutan untuk SMK Agribisnis Produksi Pertanian. Prosiding Seminar Nasional Pendidikan IPA Pascasarjana UM, vol 1: 542-548.

[9] Ghavifekr, S. \& Rosdy, W.A.W. 2015. Teaching and Learning with Technology: Effectiveness of ICT Integration in Schools. International Journal of Research in Education and Science (IJRES), 1(2): 175-191. https://doi.org/10.21890/ijres.23596

[10] Guruddin, Fatmawati. 2018. Manajemen Kurikulum untuk Meningkatkan Mutu Pendidikan Islam. Tesis (Online). Malang: Universitas Islam Negeri Maulana Malik.

[11] Shahroom, A. A., \& Hussin, N. 2018. Industrial Revolution 4.0 and Education. International Journal of Academic Research in Business and Social Sciences, 8(9): 314-319.

[12] Embong, Abd Mutalib, \& Noor, Azelin M. 2012. E-Books as Textbooks in the Classroom. Procedia - Social and Behavioral Sciences, 47: 1802 - 1809. https://doi.org/10.1016/j.sbs pro.2012.06.903

[13] Nurzaman. 2017. The Use of Problem-Based Learning Model to Improve Quality Learning Students Morals. Journal of Education and Practice, 8 (9): 2017.

[14] Suyanto. \& Jihad, A. (2016). Menjadi Guru Profesional: Strategi Meningkatkan Kualifikasi dan Kualitas Guru di era Global. Jakarta: Esensi Divisi Erlangga.

[15] Windiyati, Hestina. 2017. Praksis Strategi Pembelajaran Kejuruan Bidang Agribisnis Abad 21. Jurnal Taman Vokasi, 5 (2): 160-168. https://doi.org/10.30738/jtvok.v5i2.2474

[16] Chandrasena. Premawardhena, N., ICT in the foreign language classroom in Sri Lanka: A journey through a decade. 10th World Conference on Computers in Education (WCCE 2013), Nicolaus Copernicus University, July 2-5 2013, Torun, Poland,pp 223-224.

[17] Chandrasena. Premawardhena, N. 2012. Introducing Computer Aided Language Learning to Sri Lankan Schools: Challenges and Perspectives. 15th International Conference on Interactive Collaborative Learning and 41st International Conference on Engineering Pedagogy (ICL \& IGIP), Villach, Austria. https://doi.org/10.1109/icl.2012.6402118

[18] Alaimo, Angela \& Bruscarosco, Anna., dkk. 2017. Same World Edu-Kit. Roma: CIES Onlus.

[19] Dirjen Pendidikan Dasar dan Menengah. 2008. Panduan Pengembangan Bahan Ajar. Jakarta: Depdiknas.

[20] Nur, Mohammad. 2006. Model Pembelajaran berdasarkan Masalah. Surabaya: LPMP Ditjen PMTK Depdiknas.

[21] Peodaril, Martin \& Hrmo, Roman. 2013. Introduction of a Quality Management System for Vocational Education and Training in Slovakia. International Journal of Engineering Pedagogy, 3 (3): 2013.

[22] Astrian, Diah., Susilo, Herawati., \& Purnomo, Aris Rudi. 2020. Mind Mapping in Learning Models: A Tool to Improve Student Metacognitive Skills. International Journal of Emerging Technologies in Learning, 15 (6): 2020. https://doi.org/10.3991/ijet.v15i06.12 $\underline{657}$

[23] Karagiannidis, C., Kouroupetroglou, C., \& Koumpis, A. 2012. Special Needs at Different Educational Levels: A Forecast of 2020.ind Mapping in Learning Models: A Tool to Im- 
prove Student Metacognitive Skills. International Journal of Emerging Technologies in Learning, 7 (4): 2012. https://doi.org/10.3991/ijet.v7i4.2168

[24] Darmaji., Kurniawan, Dwi Agus., \& Astalini. 2012. Mobile Learning in Higher Education for The Industrial Revolution 4.0: Perception and Response of Physics Practicum. International Journal of Interactive Mobile Technologies, 13 (9): 2019. https://doi.org/10. 3991/ijim.v13i09.10948

[25] Maulana, Ilham Tri., hary, Restyaliza Dhini., \& Purwasih, Ratih. 2019. Project-Based Learing Model Practicality on Local Network Devices Installation Subject. International Journal of Emerging Technologies in Learning, 14 (15): 2019. https://doi.org/10.3991/ijet. $\underline{\mathrm{v} 14 \mathrm{i} 15.10305}$

\section{Authors}

Sofiana Nur Fadilah is a Chemistry Education Graduate student, Faculty of Mathematics and Science. State University of Malang. Jl. Semarang 5, Malang, Indonesia. (email: sofiana.nurfadilah@gmail.com).

Siti Marfu'ah is a Lecturer in the Chemistry Department of Mathematics and Science Faculty of Malang State University, Jl. Semarang 5, Malang, Indonesia. (email: siti.marfuah.fmipa@um.ac.id)

Surjani Wonorahardjo is a Lecturer in the Chemistry Department of Mathematics and Science Faculty of Malang State University. PUI-PT Disruptive Learning Innovation, State University of Malang, Jl. Semarang 5 Malang, Indonesia.

(email: surjani.wonorahardjo@um.ac.id)

Article submitted 2020-03-23. Resubmitted 2020-05-18. Final acceptance 2020-05-25. Final version published as submitted by the authors. 